\title{
Revival and emended description of 'Mycobacterium paraffinicum' Davis, Chase and Raymond 1956 as Mycobacterium paraffinicum sp. nov., nom. rev.
}

\author{
Nadege Toney, Toidi Adekambi, Sean Toney, Mitchell Yakrus \\ and W. Ray Butler
}

Correspondence W. Ray Butler wrb1@CDC.gov

\author{
Mycobacteriology Branch, Division of Tuberculosis Elimination, Centers for Disease Control and \\ Prevention, Atlanta, GA, USA
}

\begin{abstract}
The omission of the name 'Mycobacterium paraffinicum' from the Approved Lists of Bacterial Names was due to phenotypic confusion surrounding a close relationship with Mycobacterium scrofulaceum. Correspondingly, ' $M$. paraffinicum' strains grew slowly in $>7$ days, stained acidalcohol-fast and produced yellow-pigmented, smooth, waxy colonies in the dark at an optimal temperature of $35{ }^{\circ} \mathrm{C}$. However, ' $M$. paraffinicum' strains demonstrated no activity for urease, nicotinamidase or pyrazinamidase and lacked growth at $42{ }^{\circ} \mathrm{C}$, unlike $M$. scrofulaceum. The mycolic acid pattern, as determined by HPLC, clustered ' $M$. paraffinicum' with $M$. scrofulaceum, Mycobacterium avium and Mycobacterium parascrofulaceum. Strains were fully susceptible to linezolid, rifabutin, clarithromycin and amikacin. Examination of the historical reference strain of ' $M$. paraffinicum', ATCC 12670, and five additional isolates using comparative studies with $16 \mathrm{~S}$ rRNA, hsp65 and rpoB gene and concatenated sequences showed that they formed a tight taxonomic group that was distinct from similar non-tuberculous mycobacteria. Multilocus enzyme electrophoresis (MEE) analysis confirmed a close association of the five additional isolates with the reference strain of ' $M$. paraffinicum' with a genetic distance of 0.12 and showed that all six strains were distinct from other closely related species. These genetic results provided unambiguous evidence of the uniqueness of this slowly growing, scotochromogenic species and supported the revival of the name as Mycobacterium paraffinicum (ex Davis, Chase and Raymond 1956) sp. nov., nom. rev. We propose the previously deposited reference strain ATCC $12670^{\top}$ $=\mathrm{DSM} 44181^{\top}=\mathrm{NCIMB} 10420^{\top}$, located in collections worldwide, as the type strain.
\end{abstract}

In 1956, multiple strains of a soil bacterium were isolated below the level of grass roots in oily pools. They were characterized as Gram-positive, acid-alcohol-fast, nonmotile, rod-shaped bacilli, with white colonies that became yellow with age and were waxy and wrinkled on selective isolation medium of mineral salts agar in a gaseous atmosphere of $40 \%$ ethane in air. Subsequently, the

Abbreviations: IWGMT, International Working Group on Mycobacterial Taxonomy; MEE, multilocus enzyme electrophoresis; NTM, non-tuberculous mycobacterium.

The GenBank/EMBL/DDBJ accession numbers for the 16S rRNA, hsp65 and rpoB gene sequences of isolates 90683, 90750, 30760, 70769 and 80776 and 'M. paraffinicum' ATCC 12670 are respectively GQ153265-GQ153270 (16S rRNA gene), GQ153283-GQ153288 (hsp65) and GQ153299-GQ153304 (rpoB).

A comparison of mycolic acid patterns, a dendrogram based on ETs and neighbour-joining trees based on $h s p 65, r p o B$ and concatenated sequences are available as supplementary material with the online version of this paper. bacteria were grown on ethanol- and acetate-containing medium and the name 'Mycobacterium paraffinicum' was suggested to represent a paraffinic, gaseous hydrocarbonutilizing, non-tuberculous mycobacterium (NTM). The proposed name was 'meant to connote the general utilization of gaseous and liquid paraffinic hydrocarbons' (Davis et al., 1956). Furthermore, these mycobacteria were abundant in soil samples of petroliferous emanation, principally oilfields, and demonstrated specificity for ethane and higher paraffinic hydrocarbons (Davis et al., 1959).

Taxonomy specialists affiliated with the International Working Group on Mycobacterial Taxonomy (IWGMT) conducted co-operative, numerical taxonomic open-ended studies of NTM that included ' $M$. paraffinicum' strain ATCC $12670=$ IWGMT OES 90139. An early study of slowly growing scotochromogenic mycobacteria of Runyon's group II used 140 characters to develop an $n \times n$ matrix table to demonstrate clustering behaviour of 
the study species (Wayne et al., 1971). The IWGMT noted that cluster 4 included Mycobacterium scrofulaceum ATCC $19981^{\mathrm{T}}$ and 'M. paraffinicum' ATCC 12670 (Davis et al., 1956). They found that the fit of ' $M$. paraffinicum' was poor in the cluster and concluded that its status as a separate species was uncertain. In 1976, the Judicial Commission of the International Committee on Systematic Bacteriology suggested a comprehensive review of names of bacteria to eliminate confusing, illegitimate or invalid names and recommended the retention of names for taxa with complete descriptions (Skerman et al., 1980). The effective date of publication of these Approved Lists of Bacterial Names was 1 January 1980 in the International Journal of Systematic Bacteriology. In preparation for this change, taxonomy experts representing the genus $\mathrm{Myco-}$ bacterium published a preliminary list of species for comment in 1976 (Kubica, 1978). The name 'M. paraffinicum' appeared on this list under the heading 'commonly encountered mycobacterial species names without legitimate standing' and noted 'synonymous with $\mathrm{Myco-}$ bacterium scrofulaceum; status as a separate species still to be determined'. When the Approved Lists were published in 1980, 'M. paraffinicum' was excluded because it was not clearly distinguishable from other species with the standard methods of analysis available at that time. Shortly thereafter, the IWGMT published on slowly growing mycobacteria with numerical taxonomic methods using 178 study characters (Wayne et al., 1981). They detected 10 clusters, and ' $M$. paraffinicum' ATCC 12670 was positioned in cluster 7 and was distinguished from M. scrofulaceum by differences in pyruvate utilization, urease, nicotinamidase, pyrazinamidase and tellurite reduction. Also, the intracluster matching score suggested the species to be a unique taxon. The IWGMT agreed that proposing the revival of the name was outside the purpose of their group and recommended that the individuals who had introduced the strain should do the work. However, the IWGMT continued to include ' $M$. paraffinicum' in subsequent numerical taxonomic studies, but noted that it was premature to revive the name as the status of the species was unclear because it could not be distinguished with confidence from M. scrofulaceum (Wayne et al., 1983, 1989). The IWGMT recommended semantide-based comparative studies to determine whether the name ' $M$. paraffinicum' should be revived or placed as an outlier to known species. Another IWGMT study concluded that the characteristics of 'M. paraffinicum' conformed moderately to strains of the third intermediate category of scotochromogenic slow growers associated with ' $M$. avium-Mycobacterium intracellulare-M. scrofulaceum (MAIS) intermediate terminology' (Wayne et al., 1991). However, the species was phenotypically dissimilar to Mycobacterium avium-Mycobacterium intracellulare (MAC) species, and it was recommended that the strains be referred to by an informal vernacular term, 'the paraffinicum group' (Wayne et al., 1991). IWGMT studies consistently acknowledged that the study strain OES 90139 represented a distinct taxon but, despite the evidence for retaining the name, it was judged insufficient due to the study of a single reference isolate. In 1992, a review of infrequently encountered mycobacterial diseases acknowledged that semantide studies had not been applied to the species ' $M$. paraffinicum' but noted that the isolate had obviously different biochemical responses from M. scrofulaceum and possibly belonged to a discrete environmental species (Wayne \& Sramek, 1992).

The 16S rRNA gene sequence for ' $M$. paraffinicum' ATCC 12670 was deposited in the NCBI nucleotide database as GenBank accession number X88925, albeit with ambiguities (Springer et al., 1995). This study showed that ' $M$. paraffinicum' was closely related to $M$. scrofulaceum, with a Hamming distance of 3 for the 16S rRNA gene sequence. However, the IWGMT concluded that the single reference strain did not exhibit unequivocal taxonomic relatedness and that the name should not be revived until polyphasic studies were completed (Wayne et al., 1996). Subsequent comparative sequencing studies showed that the ' $M$. paraffinicum' ATCC $1267016 \mathrm{~S}$ rRNA gene was unique but genetically close to that of M. scrofulaceum ATCC $19981^{\mathrm{T}}$ (Turenne et al., 2001). Hybridization of distinct signature regions within the first $500 \mathrm{bp}$ of the $5^{\prime}$ end of the $16 \mathrm{~S}$ rRNA gene with commercial test kits for Line probe technology positioned 'M. paraffinicum'-M. scrofulaceum in a complex (Russo et al., 2006). However, matrix-assisted laser desorption ionization-time of flight mass spectrometry analysis of base-specific cleavage products of the PCR-amplified 16S rRNA gene unambiguously distinguished ' $M$. paraffinicum' from M. scrofulaceum (Lefmann et al., 2004). Species ambiguity remained, with other methods such as $h s p 65$ restriction fragment length polymorphisms being problematic for ' $M$. paraffinicum', as this technique identified ' $M$. paraffinicum' as $M$. avium, despite a suggestion that ' $M$. paraffinicum' was 'perhaps synonymous to $M$. scrofulaceum' (Hafner et al., 2004). Conversely, sequence analysis of this same $h s p 65$ gene region produced a separate branch distribution for ' $M$. paraffinicum' compared with M. scrofulaceum (McNabb et al., 2004), but doubt persisted regarding the validity of the name.

Comparative polyphasic studies were impeded because of a lack of strains necessary to clarify the taxonomic position of ' $M$. paraffinicum'. Researchers would not name the species based upon a single reference isolate, even though the reference strain was shown to occupy a unique taxonomic position in the genus Mycobacterium. We used phylogenetic and comparative genetic analysis of six strains to demonstrate conclusively that ' $M$. paraffinicum' is a distinct species. In this report, we propose the revival of 'Mycobacterium paraffinicum' in accordance with the rules of the International Code of Nomenclature of Prokaryotes (formerly the International Code of Nomenclature of Bacteria; the Bacteriological Code) (Lapage et al., 1992).

Type strains were recovered from our collection at $-70{ }^{\circ} \mathrm{C}$ storage. Some strains originated from the former Trudeau Mycobacteria Culture Collection (TMC) and, for clarification, current ATCC designations are included. Control 
strains included the reference strain of ' $M$. paraffinicum', ATCC 12670 , M. avium subsp. avium TMC $724^{\mathrm{T}}=$ ATCC $25291^{\mathrm{T}}$, M. scrofulaceum TMC $1323^{\mathrm{T}}=$ ATCC $19981^{\mathrm{T}}$, Mycobacterium parascrofulaceum CIP $108112^{\mathrm{T}}$ and Mycobacterium chimaera CIP $107892^{\mathrm{T}}$. An additional five isolates (strains 90683, 70769, 80776, 30760 and 90750) sent from various US public health departments were identified in our laboratory by matching 16S rRNA gene sequences (Rogall et al., 1990; Turenne et al., 2001; Charles et al., 2005; Wang et al., 2008) with the 'M. paraffinicum' reference strain and grouping by mycolic acid analysis with HPLC (Butler \& Guthertz, 2001). Strain 90750 was from a bronchial lavage and the remaining isolates were isolated from sputum. For subsequent testing of slowly growing mycobacteria, cells were incubated at $35{ }^{\circ} \mathrm{C}$ in Middlebrook $7 \mathrm{H} 9$ broth or on $7 \mathrm{H} 11$ plates or Löwenstein-Jensen (LJ) medium (Lévy-Frébault \& Portals, 1998).

Investigation of antimicrobial susceptibility was done using broth microdilution with Sensititre SLOWMYCO plates (Trek Diagnostic Systems) according to the manufacturer's instructions. Individual plates included both positive and negative growth controls. M. avium ATCC $25291^{\mathrm{T}}$ was included as a control for validation of results (Woods et al., 2003; Wallace et al., 1986; Heifets, 1988). Susceptibility testing was done with ' $M$. paraffinicum' ATCC 12670 and the five additional isolates. Susceptibilities were determined by microdilution broth MICs (CLSI, 2009; NCCLS, 2003). For comparative analysis, similar mycobacteria controls included M. avium ATCC $25291^{\mathrm{T}}$, M. scrofulaceum ATCC $19981^{\mathrm{T}}$ and $M$. parascrofulaceum CIP $108112^{\mathrm{T}}$. Antimicrobials tested were amikacin, rifabutin, ciprofloxacin, clarithromycin, ethambutol, gatifloxacin, linezolid, minocycline, moxifloxacin, rifampicin, streptomycin and trimethoprim/sulfamethoxazole.

Mycolic acids were examined by HPLC according to previously published procedures (Butler \& Guthertz, 2001).

Electrophoretic mobilities of six cellular enzymes were determined using multilocus enzyme electrophoresis (MEE) by previously published methods for typing of NTM (Yakrus et al., 1992). The enzymes studied were adenylate kinase, glutamate oxaloacetate transaminase, phosphoglucoisomerase, benzyl alcohol dehydrogenase, aconitase and phosphoglucomutase.

DNA was extracted from $200 \mu \mathrm{l}$ of a $7 \mathrm{H} 9$ bacterial suspension by bead beating in a $2 \mathrm{ml}$ tube containing $250 \mu \mathrm{l} 0.1 \mathrm{~mm}$ zirconium beads suspended in $300 \mu \mathrm{l} \mathrm{TE}$ buffer (10 mM Tris/HCl, $1 \mathrm{mM}$ EDTA, pH 8.0). Cells were lysed with a FastPrep FP120 instrument (Qbiogene) set at $6.0 \mathrm{~ms}^{-1}$ for $45 \mathrm{~s}$ and a biphasic separation was achieved by adding $300 \mu \mathrm{l}$ chloroform. The resulting solution was centrifuged in a microcentrifuge at 14000 r.p.m. for $5 \mathrm{~min}$ to separate the layers. The DNA-containing aqueous TE layer was transferred to a sterile tube, heated to $90 \pm 5{ }^{\circ} \mathrm{C}$ for $30 \mathrm{~min}$ and stored at $4{ }^{\circ} \mathrm{C}$ until used in subsequent PCR amplification. The 16S rRNA gene was amplified and sequenced with the same primer pair, $\mathrm{fD} 1 / \mathrm{rp} 2$ (Weisburg et al., 1991). Two additional housekeeping genes, hsp65 and $r p o B$, were amplified and sequenced using, respectively, primer pairs TB11/TB12 (Telenti et al., 1993) and MycoF/MycoR (Adékambi et al., 2003). Products of sequencing reactions were recorded with an ABI Prism 3130 xl DNA sequencer following the standard protocol of the supplier (Perkin Elmer Applied Biosystems). The percentage of similarity between the sequences was determined using the CLUSTAL $\mathrm{W}$ program supported by the PBIL website (http://pbil.univ-lyon1.fr). For phylogenetic analysis, sequences were trimmed in order to start and finish at the same nucleotide position for all the strains under study. Multisequence alignment was performed by using the CLUSTAL_X program, version 1.81, with the PHYLIP software package (Thompson et al., 1997). Phylogenetic trees were compared using the maximum-parsimony, maximum-likelihood and neighbour-joining methods. One neighbourjoining tree was based upon concatenated 16S rRNA, $h s p 65$ and $r p o B$ gene sequences. The maximum-likelihood trees were reconstructed using PhyML software with GTR, gamma distribution and invariable sites as the substitution model and 100 bootstrap replications (Guindon \& Gascuel, 2003). Phylogenetic trees were obtained from DNA sequences by using the maximum-parsimony and neighbourjoining methods with 1000 bootstrap replications in MEGA version 3.1 (Kumar et al., 2004).

Strains were fully grown on mycobacteria media in 14 days at an optimum temperature of $35^{\circ} \mathrm{C}$ and stained acid-alcohol-fast, characteristic of the genus $\mathrm{Myco}$ bacterium. Extensive IWGMT polyphasic studies had suggested an affiliation of the so-called ' $M$. paraffinicum' reference strain ATCC 12670 within the genus Mycobacterium and emphasized the uniqueness of this species. IWGMT results of biochemical testing clustered this reference strain close to the scotochromogenic species M. scrofulaceum, having negative test results for Tween 80 hydrolysis, niacin production, nitrate reduction, tolerance of $5 \% \mathrm{NaCl}$ and acid phosphatase. Conversely, the taxonomic position of ' $M$. paraffinicum' was distinct, with positive tests for Tween opacity and negative results for nicotinamidase, pyrazinamidase and urease compared with M. scrofulaceum (Table 1).

The six ' $M$. paraffinicum' strains were susceptible to rifabutin, linezolid, clarithromycin and amikacin. Amikacin susceptibility was different compared with M. scrofulaceum, but the drug susceptibility patterns were generally not distinctive (Table 2).

'M. paraffinicum' cells assimilated triglycerides, glycolipids and mycolic acids in the outer layers of the cell wall, similar to species of the genus Mycobacterium (Gusev et al., 1978). Differentiation of the cellular lipid components by TLC analysis showed a similar but slightly different lipid pattern compared with M. scrofulaceum (Sehrt et al., 1976). Mycolic acid analysis with HPLC was not conclusive but demonstrated late, double-cluster HPLC patterns representative of mycobacteria. Study isolates shared characteristics of alpha, 
Table 1. Phenotypic characteristics of ' $M$. paraffinicum' ATCC 12670 and type strains of closely related species

Strains: 1, 'M. paraffinicum' ATCC 12670; 2, M. scrofulaceum ATCC 19981 ${ }^{\mathrm{T}}$; 3, M. parascrofulaceum CIP $108112^{\mathrm{T}}$; 4, M. avium ATCC $25291^{\mathrm{T}}$; 5, M. nebraskense ATCC BAA- $837^{\mathrm{T}}$. Data were compiled for type strains from Davis et al. (1956), Kent \& Kubica (1985), Wayne et al. (1991, 1996), Turenne et al. (2004), Tsukamura (1984) and Mohamed et al. (2004). +, Positive; -, negative; v, variable; ND, no data available.

\begin{tabular}{|c|c|c|c|c|c|}
\hline Property & 1 & 2 & 3 & 4 & 5 \\
\hline Temperature range for growth $\left({ }^{\circ} \mathrm{C}\right)$ & $22-37$ & $22-37$ & $25-37$ & $22-45$ & $25-35$ \\
\hline Pigment production ${ }^{*}$ & s & s & s & $\mathrm{N}$ & s \\
\hline \multicolumn{6}{|l|}{ Catalase tests: } \\
\hline Semi-quantitative ( $>45 \mathrm{~mm})$ & + & + & $\mathrm{V}$ & - & - \\
\hline Heat-stable $\left(68{ }^{\circ} \mathrm{C}\right)$ & + & + & + & + & + \\
\hline Tween opacity (5 weeks) & + & - & ND & + & ND \\
\hline Tween 80 hydrolysis & - & - & - & - & $\mathrm{V}$ \\
\hline Iron uptake & ND & - & - & - & ND \\
\hline Growth on MacConkey agar & ND & - & - & - & - \\
\hline Acid phosphatase & - & - & - & - & ND \\
\hline Nicotinamidase & - & + & ND & + & ND \\
\hline Pyrazinamidase & - & + & + & + & - \\
\hline Urease & - & + & + & - & - \\
\hline Arylsulfatase (3/14 days) & $-/ \mathrm{v}(10$ days $)$ & $-1-$ & $-/ \mathrm{v}$ & $-/ \mathrm{V}$ & $-/ \mathrm{ND}$ \\
\hline
\end{tabular}

${ }^{*} \mathrm{~N}$, Non-chromogen; s, scotochromogen.

keto and epoxy wax ester mycolic acids, closely akin to species related to M. avium (Supplementary Fig. S1, available in IJSEM Online). Therefore, unambiguous species identification required molecular sequence determinations.

The MEE strain typing method was used to generate a dendrogram of genetic relationships among the isolates (Supplementary Fig. S2). Genetic distance was measured with enzyme electrophoretic types (ET) and demonstrated a highly related group with a distance of 0.124 and isolates clustered closely with the reference strain of ' $M$. paraffinicum', ATCC 12670. An exact correlation of ET was found for two of the study isolates, 90750 and 80776 . One of the study isolates, 90683, matched the reference strain of ' $M$. paraffinicum'. Three of the study isolates and the reference strain of ' $M$. paraffinicum' united at a shallow genetic distance of 0.07 . In contrast, the tightly clustered isolates of 'M. paraffinicum' were separated from M. scrofulaceum

Table 2. Antimicrobial susceptibility patterns of study strains

Strains: 1, M. avium ATCC 25291 ${ }^{\mathrm{T}}$; 2, M. scrofulaceum ATCC $19981^{\mathrm{T}} ; 3$, M. parascrofulaceum CIP $108112^{\mathrm{T}}$; 4, 'M. paraffinicum' ATCC 12670; 5, M. chimaera CIP $107892^{\mathrm{T}}$; 6 , isolate $90750 ; 7$, isolate $30760 ; 8$, isolate 70769; 9, isolate 80776; 10, isolate 90683 . CLSI or NCCLS breakpoint guidelines (CLSI, 2009; NCCLS, 2003) were used to determine susceptibilities by microdilution broth MICs ( $\mu \mathrm{g} \mathrm{ml}^{-1}$ ). Modified MIC drug susceptibility breakpoints were rifampicin $\left(\geqslant 2 \mu \mathrm{g} \mathrm{ml}^{-1}\right)$, ethambutol $\left(\geqslant 4 \mu \mathrm{g} \mathrm{ml}^{-1}\right)$, trimethoprim/sulfamethoxazole $\left(4 / 76 \mu \mathrm{g} \mathrm{ml}^{-1}\right)$ and minocycline $(\geqslant 8 \mu \mathrm{g}$ $\mathrm{ml}^{-1}$ ). Intermediate breakpoints were interpreted as drug resistant. Underlined MICs demonstrate drug susceptibility.

\begin{tabular}{|c|c|c|c|c|c|c|c|c|c|c|}
\hline Antimicrobial & 1 & 2 & 3 & 4 & 5 & 6 & 7 & 8 & 9 & 10 \\
\hline Ciprofloxacin & 2 & 8 & $>16$ & 8 & 16 & 1 & 8 & 1 & 1 & 4 \\
\hline Gatifloxacin & 1 & 2 & 4 & 8 & $>8$ & 0.25 & 8 & 0.5 & 0.5 & 2 \\
\hline Moxifloxacin & $\overline{1}$ & 0.5 & 2 & 2 & 8 & $\overline{0.5}$ & 4 & $\overline{0.5}$ & $\overline{0.5}$ & $\overline{1}$ \\
\hline Linezolid & 16 & 8 & $\underline{8}$ & $\underline{8}$ & 52 & 4 & 8 & 2 & 4 & $\underline{4}$ \\
\hline Rifampicin & 1 & $\underline{1}$ & 0.25 & $\overline{4}$ & $>8$ & $\leq 0.06$ & $\underline{1}$ & $0 . \overline{25}$ & $\underline{1}$ & 0.5 \\
\hline Rifabutin & $<0.06$ & $<0.06$ & $\overline{0.12}$ & 0.5 & 1 & $\overline{<0.06}$ & 0.12 & $\overline{0.12}$ & $<0.06$ & $\overline{0.12}$ \\
\hline Trimethoprim/sulfamethoxazole & $\overline{2 / 38}$ & $\overline{>8 / 152}$ & $\overline{4 / 76}$ & $>\overline{8 / 152}$ & $8 / \overline{152}$ & $\overline{0.5 / 9.5}$ & $\overline{2 / 38}$ & $\overline{1 / 19}$ & $\overline{1 / 19}$ & $\overline{4 / 76}$ \\
\hline Minocycline & 16 & $>32$ & 8 & 32 & 32 & 4 & 16 & 4 & 32 & 8 \\
\hline Ethambutol & $>32$ & $>32$ & $\overline{32}$ & 16 & $>32$ & $\overline{8}$ & 8 & $\overline{8}$ & 32 & $\overline{16}$ \\
\hline Clarithromycin & $<0.5$ & 8 & $<0.5$ & $<0.5$ & 8 & $<0.5$ & $<0.5$ & $<0.5$ & $<0.5$ & $<0.5$ \\
\hline Amikacin & 8 & 32 & 4 & 8 & 32 & 1 & 2 & 8 & 16 & 2 \\
\hline Streptomycin & $\overline{8}$ & 32 & $\overline{8}$ & $\overline{8}$ & 16 & $\overline{4}$ & $\overline{1}$ & $\overline{8}$ & $\overline{16}$ & 2 \\
\hline
\end{tabular}


ATCC $19981^{\mathrm{T}}$ and M. parascrofulaceum CIP $108112^{\mathrm{T}}$ by a genetic distance of 0.29 . Since reference isolates $M$. scrofulaceum ATCC $19981^{\mathrm{T}}$ and M. parascrofulaceum CIP $108112^{\mathrm{T}}$ were separated by a relative genetic distance of 0.216 , the MEE results provided evidence that the cluster of 'M. paraffinicum' isolates represented a separate species.

The IWGMT semantide-based study emphasized a variety of characteristics that were definitive for ' $M$. paraffinicum', including $16 \mathrm{~S}$ rRNA gene sequencing, alpha-antigen analysis, T-catalase analysis and results from different DNADNA hybridization tests (Wayne et al., 1996). The fluorimetric DNA-DNA hybridization results were correlated with the recommended $70 \%$ DNA cut-off value for species and defined the reference strain of ' $M$. paraffinicum' as unique. They demonstrated that the reference strain was 'an isolated strain that exhibits no unequivocal taxonomic relatedness to any other known culture' (Wayne et al., 1996). Although a whole-genome reference DNA probe hybridization method showed a positive reaction with $M$. scrofulaceum, it was acknowledged that the control probe set did not contain a DNA probe for M. paraffinicum and only included an M. scrofulaceum probe. We confirmed the genetic affiliation with phylogenetic analysis of the $16 \mathrm{~S}$ rRNA gene for the reference strain and for the five additional strains and demonstrated the distinct monophyletic tree branching of ' $M$. paraffinicum' within the pigmented, slowly growing mycobacteria. Using almostcomplete 16S rRNA gene sequences (1483 bp), ' $M$. paraffinicum' isolates exhibited a unique sequence on a separate phylogenetic tree branch with 99.8, 98.7 and $98.4 \%$ similarity to the type strains of $M$. scrofulaceum, Mycobacterium nebraskense and Mycobacterium malmoense, respectively (Fig. 1). No intraspecies variation was found. Further comparative study using hsp65 sequencing (401 bp) showed that the ' $M$. paraffinicum' isolates exhibited 96.0, 96.0, 95.0 and $96.5 \%$ similarity, respectively, to the type strains of M. scrofulaceum, M. parascrofulaceum, M. nebraskense and M. malmoense and that these species were on a distinct branch (Supplementary Fig. S3). An analogous result was revealed by comparing $745 \mathrm{bp}$ of the rpoB gene; the ' $M$. paraffinicum' isolates exhibited
94.7, 96.2 and $90.7 \%$ similarity, respectively, to the type strains of $M$. scrofulaceum, $M$. nebraskense and $M$. malmoense, and these species were on a separate branch (Supplementary Fig. S4). No intraspecies variation was found. The $r p o B$ nucleotide sequence similarity was below the $97.1 \%$ cut-off value recommended for new species recognition (Adékambi \& Drancourt, 2004). A phylogenetic tree consisting of concatenated 16S rRNA, hsp65 and $r p o B$ housekeeping gene sequences (2629 bp) demonstrated genetic robustness and clearly discriminated the 'M. paraffinicum' isolates on a separate branch (Supplementary Fig. S5).

The recent description of Mycobacterium seoulense indicated a close $16 \mathrm{~S}$ rRNA gene relationship ( $>99 \%$ sequence similarity) with $M$. scrofulaceum and $M$. nebraskense and implied a possible association with ' $M$. paraffinicum'. However, GenBank comparative BLAST alignments of the 16S rRNA gene of $M$. seoulense 03-19 ${ }^{\mathrm{T}}$ (accession no. DQ536403; Mun et al., 2007) with 'M. paraffinicum' ATCC 12670 (GQ153270) demonstrated differences in 12 positions, and the branching of the $16 \mathrm{~S}$ rRNA gene tree showed a divergent position for M. seoulense (Fig. 1).

'M. paraffinicum' was described as an environmental NTM specifically associated with hydrocarbon-laden soil beneath sludge ponds in oil and gas production sites, but a lack of study cultures prevented semantide studies as recommended by IWGMT (Wayne \& Sramek, 1992). The strain that provided the sequence deposited in GenBank was designated the reference strain of ' $M$. paraffinicum' but the name has not been validly published. However, the name is not on the list of rejected names (nomina rejicienda; Rule 56a of the Bacteriological Code; Lapage et al., 1992) and is therefore available for valid publication. Molecular systematics of multiple strains clearly supported the revival of the name. Therefore, after more than five decades of taxonomic confusion, we propose the revival of the name 'Mycobacterium paraffinicum' as a nomen revictum (Rules $28 \mathrm{a}$ and $33 \mathrm{c}$ of the Bacteriological Code) for the same organism to which the name was originally applied. It is our intent that the revival of the name be perpetuated in

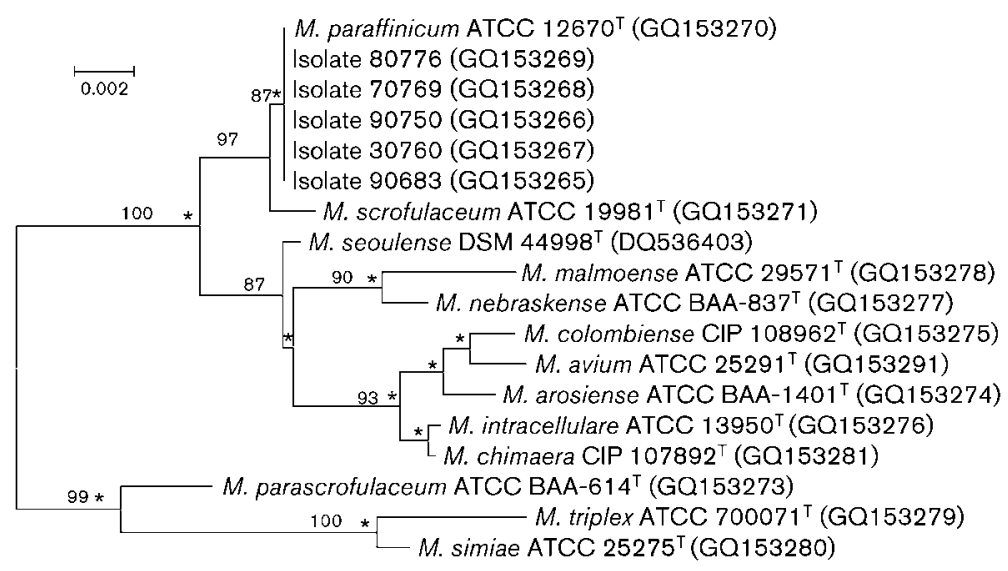

Fig. 1. Neighbour-joining phylogenetic tree based on $1483 \mathrm{bp}$ of the 16S rRNA gene sequence from multiple strains of ' $M$. paraffinicum'. Asterisks at nodes indicate common groupings also demonstrated in the maximumparsimony and maximum-likelihood trees (not shown). The tree is unrooted and shows closely related species. Mycobacterium species with known nomenclature are noted with strain designations and GenBank accession numbers. Bootstrap percentages are provided at branch points. Bar, $0.2 \%$ difference in nucleotide sequences. 
subsequent revisions to include the original authors (revised Rule 33c; Young \& Euzéby, 2008). The original 1956 isolate that was deposited as ATCC 12670 is designated the type strain of Mycobacterium paraffinicum. Strains in other international collections originated from this original ATCC deposit and are listed in this publication. This type strain has been deposited in multiple collections as noted below and satisfies the requirements of the Bacteriological Code for deposit of type cultures in two or more collections in different countries.

Extensive physiological characteristics are given in earlier studies (Davis et al., 1956; Wayne et al., 1989, 1991, 1996).

\section{Description of Mycobacterium paraffinicum (ex Davis et al. 1956) sp. nov., nom. rev.}

Mycobacterium paraffinicum (par.af.fi'ni.cum. N.L. n. paraffinicum paraffin; L. neut. suff. -icum suffix used with the sense of pertaining to; N.L. neut. adj. paraffinicum pertaining to paraffin).

The original description of 'Mycobacterium paraffinicum' (Davis et al., 1956) is emended to reflect genetic properties, drug MICs and the mycolic acid profile, as presented here. The description is as given by Davis et al. (1956) for a slowly growing, soil-dwelling, scotochromogenic bacterium that uses paraffinic hydrocarbons other than methane and also incorporates additional characteristics described by IWGMT studies (Wayne et al., 1989, 1991, 1996; Wayne \& Sramek, 1992). Bacilli are long, slender rods, $0.5-0.7 \mu \mathrm{m}$ wide and 3.0-7.0 $\mu \mathrm{m}$ long. Cells are non-motile, Gram-positive and acid-alcohol-fast, with terminal stained granules. Colonies are yellow, waxy and smooth or wrinkled on LJ medium. Grows on Middlebrook 7H10 and 7H11 agar and in 7H9 broth. Growth occurs slowly, in $>7$ days. Growth at $22{ }^{\circ} \mathrm{C}$ is stunted; optimum growth at $35{ }^{\circ} \mathrm{C}$ and no growth at $45^{\circ} \mathrm{C}$. Typical biochemical characteristics of the species are negative tests for urease, nicotinamidase and pyrazinamidase and positive results for Tween opacity ( 5 weeks). Strains are susceptible to amikacin, rifabutin, clarithromycin and linezolid and resistant to ethambutol. Cell walls contain alpha, keto and wax ester mycolic acids characteristic of species associated with the Mycobacterium avium complex. Conclusive identification is by molecular sequence analysis of the $16 \mathrm{~S}$ rRNA, $h s p 65$ or $r p o B$ gene.

The type strain is ATCC $12670^{\mathrm{T}}\left(=\mathrm{DSM} 44181^{\mathrm{T}}=\mathrm{NCIMB}\right.$ $10420^{\mathrm{T}}$ ), deposited by J. B. Davis, Magnolia Petroleum Co., Easton, LA, USA, in the ATCC in 1956.

\section{Acknowledgements}

We are grateful to Hans G. Trüper for assistance with the proper etymology of the name.

\section{References}

Adékambi, T. \& Drancourt, M. (2004). Dissection of phylogenetic relationships among 19 rapidly growing Mycobacterium species by $16 \mathrm{~S}$
rRNA, hsp65, recA and rpoB gene sequencing. Int J Syst Evol Microbiol 54, 2095-2105.

Adékambi, T., Colson, P. \& Drancourt, M. (2003). rpoB-based identification of nonpigmented and late-pigmenting rapidly growing mycobacteria. J Clin Microbiol 41, 5699-5708.

Butler, W. R. \& Guthertz, L. S. (2001). Mycolic acid analysis by highperformance liquid chromatography for identification of Mycobacterium species. Clin Microbiol Rev 14, 704-726.

Charles, N., Toney, S. R. \& Butler, W. R. (2005). Identification of mycobacteria by $16 S$ rRNA gene sequencing and HPLC analysis of mycolic acids in a reference laboratory. In Abstracts of the 105th General Meeting of the American Society for Microbiology, 5-10 June 2005, Atlanta, GA, USA, abstract U-042. Washington, DC: American Society for Microbiology.

CLSI (2009). Performance standards for antimicrobial susceptibility testing, 19th Informational Supplement. CLSI document M100-S19 (ISBN 1-56238-690-5). Wayne, PA: Clinical and Laboratory Standards Institute.

Davis, J. B., Chase, H. H. \& Raymond, R. L. (1956). Mycobacterium paraffinicum n. sp., a bacterium isolated from soil. Appl Microbiol 4, 310-315.

Davis, J. B., Raymond, R. L. \& Stanley, J. P. (1959). Areal contrasts in the abundance of hydrocarbon oxidizing microbes in soils. Appl Microbiol 7, 156-165.

Guindon, S. \& Gascuel, O. (2003). A simple, fast, and accurate algorithm to estimate large phylogenies by maximum likelihood. Syst Biol 52, 696-704.

Gusev, M. V., Koronelli, T. V. \& Korolev, I. N. (1978). Study of the dynamics of the uptake and utilization of a hydrocarbon in Mycobacterium paraffinicum cells by means of IR-spectroscopy. Mikrobiologiia 47, 1025-1029 (in Russian).

Hafner, B. H., Haag, H., Geiss, H-K. \& Nolte, O. (2004). Different molecular methods for the identification of rarely isolated nontuberculous mycobacteria and description of new hsp65 restriction fragment length polymorphism patterns. Mol Cell Probes 18, 59-65.

Heifets, L. (1988). MIC as a quantitative measurement of the susceptibility of Mycobacterium avium strains to seven antituberculosis drugs. Antimicrob Agents Chemother 32, 1131-1136.

Kent, P. T. \& Kubica, G. P. (1985). Public Health Mycobacteriology: a Guide for the Level III Laboratory. Atlanta: Centers for Disease Control, US Department of Public Health \& Human Services.

Kubica, G. P. (1978). Committee on Bacteriology and Immunology: the current nomenclature of the mycobacteria - 1978. Bull Int Union Tuberc 53, 211-217.

Kumar, S., Tamura, K. \& Nei, M. (2004). MEGA3: integrated software for molecular evolutionary genetics analysis and sequence alignment. Brief Bioinform 5, 150-163.

Lapage, S. P., Sneath, P. H. A., Lessel, E. F., Skerman, V. B. D., Seeliger, H. P. R. \& Clark, W. A. (editors) (1992). International Code of Nomenclature of Bacteria (1990 revision). Bacteriological Code. Washington, DC: American Society for Microbiology.

Lefmann, M., Honisch, C., Böcker, S., Storm, N., von Wintzingerode, F., Schlötelburg, C., Moter, A., van den Boom, D. \& Göbel, U. B. (2004). Novel mass spectrometry-based tool for genotypic identification of mycobacteria. J Clin Microbiol 42, 339-346.

Lévy-Frébault, V. V. \& Portals, F. (1998). Proposed minimal standards for the genus Mycobacterium and for description of new slowly growing Mycobacterium species. Int J Syst Bacteriol 42, 315-323.

McNabb, A., Eisler, D., Adie, K., Amos, M., Rodrigues, M., Stephens, G., Black, W. A. \& Isaac-Renton, J. (2004). Assessment of partial sequencing of the 65-kilodalton heat shock protein gene (hsp65) for routine 
identification of Mycobacterium species isolated from clinical sources. J Clin Microbiol 42, 3000-3011.

Mohamed, A. M., Iwen, P. C., Tarantolo, S. \& Hinrichs, S. H. (2004). Mycobacterium nebraskense sp. nov., a novel slowly growing scotochromogenic species. Int J Syst Evol Microbiol 54, 2057-2060.

Mun, H.-S., Kim, H.-J., Oh, E.-J., Kim, H., Bai, G.-H., Yu, H.-K., Park, Y.-G., Cha, C.-Y., Kook, Y.-H. \& Kim, B.-J. (2007). Mycobacterium seoulense sp. nov., a slowly growing scotochromogenic species. Int J Syst Evol Microbiol 57, 594-599.

NCCLS (2003). Susceptibility testing of mycobacteria, nocardiae, and other aerobic actinomycetes. Approved Standard. NCCLS document M24-A (ISBN 1-56238-500-3). Wayne, PA: National Committee on Clinical Laboratory Standards.

Rogall, T., Wolters, J., Flohr, T. \& Böttger, E. C. (1990). Towards a phylogeny and definition of species at the molecular level within the genus Mycobacterium. Int J Syst Bacteriol 40, 323-330.

Russo, C., Tortoli, E. \& Menichella, D. (2006). Evaluation of the new GenoType Mycobacterium assay for identification of mycobacterial species. J Clin Microbiol 44, 334-339.

Sehrt, I., Kappler, W. \& Lange, A. (1976). Differentiation and identification of mycobacteria by means of thin-layer chromatography of their lipids. III. Application for the classification of scotochromogenic mycobacteria. Z Erkr Atmungsorgane 145, 196-201 (in German).

Skerman, V. B. D., McGowan, V. \& Sneath, P. H. A. (editors) (1980). Approved lists of bacterial names. Int J Syst Bacteriol 30, 225-420.

Springer, B., Tortoli, E., Richter, I., Grünewald, R., Rüsch-Gerdes, S., Uschmann, K., Suter, F., Collins, M. D., Kroppenstedt, R. M. \& Böttger, E. C. (1995). Mycobacterium conspicuum sp. nov., a new species isolated from patients with disseminated infections. J Clin Microbiol 33, 2805-2811.

Telenti, A., Marchesi, F., Balz, M., Bally, F., Böttger, E. \& Bodmer, T. (1993). Rapid identification of mycobacteria to the species level by polymerase chain reaction and restriction enzyme analysis. J Clin Microbiol 31, 175-178.

Thompson, J. D., Gibson, T. J., Plewniak, F., Jeanmougin, F. \& Higgins, D. G. (1997). The CLUSTAL_X windows interface: flexible strategies for multiple sequence alignment aided by quality analysis tools. Nucleic Acids Res 25, 4876-4882.

Tsukamura, M. (1984). Identification of Mycobacteria. Obu, Aichi, Japan: National Chubu Hospital.

Turenne, C. Y., Tschetter, L., Wolfe, J. \& Kabani, A. (2001). Necessity of quality controlled $16 \mathrm{~S}$ rRNA gene sequence databases: identifying nontuberculous Mycobacterium species. J Clin Microbiol 39, 36373648.

Turenne, C. Y., Cook, V. J., Burdz, T. V., Pauls, R. J., Thibert, L., Wolfe, J. N. \& Kabani, A. (2004). Mycobacterium parascrofulaceum sp. nov., novel slowly growing, scotochromogenic clinical isolates related to Mycobacterium simiae. Int J Syst Evol Microbiol 54, 1543-1551.

Wallace, R. J., Jr, Nash, D. R., Steele, L. C. \& Steingrube, V. (1986). Susceptibility testing of slowly growing mycobacteria by microdilution MIC method with 7H9 broth. J Clin Microbiol 24, 976-981.
Wang, S.-H., Mangino, J. E., Stevenson, K., Yakrus, M. A., Cooksey, R., Butler, W. R., Healy, M., Wise, M. G., Schlesinger, L. S. \& Pancholi, P. (2008). Characterization of a "Mycobacterium paraffinicum" isolate associated with a pseudo-outbreak. J Clin Microbiol 46, 1850-1853.

Wayne, L. G. \& Sramek, H. A. (1992). Agents of newly recognized or infrequently encountered mycobacterial diseases. Clin Microbiol Rev 5, 1-25.

Wayne, L. G., Dietz, T. M., Gernez-Rieux, C., Jenkins, P. A., Käppler, W., Kubica, G. P., Kwapinski, J. B. G., Meissner, G., Pattyn, S. R. \& other authors (1971). A cooperative numerical analysis of scotochromogenic slowly growing mycobacteria. J Gen Microbiol 66, 255-271.

Wayne, L. G., Good, R. C., Krichevsky, M. I., Beam, R. E., Blacklock, Z., Chaparas, S. D., Dawson, D., Forman, S. D., Gross, W. \& other authors (1981). First report of the cooperative, open-ended study of slowly growing mycobacteria by the International Working Group on Mycobacterial Taxonomy. Int J Syst Bacteriol 31, 1-20.

Wayne, L. G., Good, R. C., Krichevsky, M. I., Beam, R. E., Blacklock, Z., David, H. L., Dawson, D., Gross, W., Hawkins, J. \& other authors (1983). Second report of the cooperative, open-ended study of slowly growing mycobacteria by the International Working Group on Mycobacterial Taxonomy. Int J Syst Bacteriol 33, 265-274.

Wayne, L. G., Good, R. C., Krichevsky, M. I., Blacklock, Z., David, H. L., Dawson, D., Gross, W., Hawkins, J., Jenkins, P. A. \& other authors (1989). Third report of the cooperative, open-ended study of slowly growing mycobacteria by the International Working Group on Mycobacterial Taxonomy. Int J Syst Bacteriol 39, 267-278.

Wayne, L. G., Good, R. C., Krichevsky, M. I., Blacklock, Z., David, H. L., Dawson, D., Gross, W., Hawkins, J., Levy-Frebault, V. V. \& other authors (1991). Fourth report of the cooperative, open-ended study of slowly growing mycobacteria by the International Working Group on Mycobacterial Taxonomy. Int J Syst Bacteriol 41, 463-472.

Wayne, L. G., Good, R. C., Böttger, E. C., Butler, R., Dorsch, M., Ezaki, T., Gross, W., Jonas, V., Kilburn, J. \& other authors (1996). Semantide- and chemotaxonomy-based analyses of some problematic phenotypic clusters of slowly growing mycobacteria, a cooperative study of the International Working Group on Mycobacterial Taxonomy. Int J Syst Bacteriol 46, 280-297.

Weisburg, W. G., Barns, S. M., Pelletier, D. A. \& Lane, D. J. (1991). $16 \mathrm{~S}$ ribosomal DNA amplification for phylogenetic study. J Bacteriol 173, 697-703.

Woods, G. L., Williams-Bouyer, N., Wallace, R. J., Jr, Brown-Elliott, B. A., Witebsky, F. G., Conville, P. S., Plaunt, M., Hall, G., Aralar, P. \& Inderlied, C. (2003). Multisite reproducibility of results obtained by two broth dilution methods for susceptibility testing of Mycobacterium avium complex. J Clin Microbiol 41, 627-631.

Yakrus, M. A., Reeves, M. W. \& Hunter, S. B. (1992). Characterization of isolates of Mycobacterium avium serotypes 4 and 8 from patients with AIDS by multilocus enzyme electrophoresis. J Clin Microbiol 30, 1474-1478.

Young, J. M. \& Euzéby, J. P. (2008). Proposed revision of Rule 33c to perpetuate the citation of revived names. Int J Syst Evol Microbiol 58, 2468-2469. 